\title{
Growth Rates and Sunflower Production in Function of Fertilization with Biochar and NPK
}

\author{
Guilherme F. Furtado ${ }^{1} \&$ Lúcia Helena G. Chaves ${ }^{1}$ \\ ${ }^{1}$ Department of Agricultural Engineering, Federal University of Campina Grande, Campina Grande, Paraiba \\ State, Brazil \\ Correspondence: Lúcia Helena G. Chaves, Federal University of Campina Grande, Avenue Aprigio Veloso, 882, \\ Campina Grande, CEP 58429-140, Paraiba State, Brazil. Tel: 55-83-2101-1186. E-mail: lhgarofalo@hotmail.com
}

Received: November 15, 2017

Accepted: December 12, 2017 Online Published: January 15, 2018

doi:10.5539/jas.v10n2p260

URL: https://doi.org/10.5539/jas.v10n2p260

\begin{abstract}
The use of alternative sources such as biochar can contribute to sustainable agriculture. The objective of this study was to evaluate the effect of fertilization with biochar in combination with mineral fertilizer, growth rates and yield of sunflower cv. Embrapa 122/V2000. The experiment was carried out in a protected environment of UAEAg/CTRN/UFCG in pots with a capacity of $20 \mathrm{dm}^{3}$ under a completely randomized experimental design, with treatments arranged in a factorial scheme $(5 \times 4)$ and four replicates corresponding to five doses of mineral fertilization $0,25 \%, 50 \%, 75 \%$, and $100 \%$ of fertilization indication with NPK $\left(100,300\right.$, and $\left.150 \mathrm{mg} \mathrm{kg}^{-1}\right)$ and four doses of biochar, $0 ; 5 \%(400 \mathrm{~g} / \mathrm{pot}) ; 10 \%(800 \mathrm{~g} / \mathrm{pot})$ and $15 \%(1100 \mathrm{~g} / \mathrm{pot})$ calculated on the basis of the soil volume. Fertilization with biochar promoted an increase in sunflower growth rates in the evaluation periods. The combination of 50: 150: $75 \mathrm{mg} \mathrm{kg}{ }^{-1}$ of NPK and $400 \mathrm{~g} /$ pot of biochar promotes higher production of sunflower $(23.91 \mathrm{~g} /$ plant $)$.
\end{abstract}

Keywords: biomass, fertilization, Helianthus annuиs L.

\section{Introduction}

Sunflower (Helianthus annuus L.) is an important oilseed crops for Brazilian semiarid due to short duration, having ability to adapt wide range of climate and soil conditions providing a greater competitive advantage in relation to other crops such as soybean, for to yield higher yields in oil production per hectare (Zobiole et al., 2010). It is a very demanding crop from the nutritional point of view, and its response to fertilization is limited by the productive potential and by the nutrient export rate.

According to Prado and Leal (2006) the elements nitrogen $(\mathrm{N})$, phosphorus $(\mathrm{P})$ and potassium $(\mathrm{K})$ are the most limiting growth and dry matter production of sunflower, and from this crop accumulates a total of $41 \mathrm{~kg}$ of N; $17.1 \mathrm{~kg}$ of $\mathrm{P}_{2} \mathrm{O}_{5}$ and $171 \mathrm{~kg}$ of $\mathrm{K}_{2} \mathrm{O}$ to produce one ton of grain (Castro \& Oliveira, 2005). However, according to Zobiole et al. (2010) about 90 to $95 \%$ of the amount of absorbed $\mathrm{K}$ can return to the soil with the mineralization of the cultural remains.

There are various factors responsible for obtaining the higher yield of sunflower such as fertilizing that improves the yield as well as quality of this crop. According to Campos et al. (2012), the fertilization with $60 \mathrm{~kg} \mathrm{ha}^{-1}$ of N; $80 \mathrm{~kg} \mathrm{ha}^{-1}$ of $\mathrm{P}_{2} \mathrm{O}_{5}$ and $80 \mathrm{~kg} \mathrm{ha}^{-1}$ of $\mathrm{K}_{2} \mathrm{O}$ provides the best quality of sunflower inflorescences cv. Embrapa 122/V2000. Among the new technologies that reduce environmental impact and improve agricultural production, the use of biochar, which according to Madari et al. (2012) is among the only available technologies that can contribute to the improvement or maintenance of soil properties and thus to the production of sustainable energy and food.

The biochar is an organic compound produced by the fast or slow pyrolysis process. It can be applied to the soil, improving its physical and chemical properties (Lehmann et al., 2006). Pyrolysis is defined as the thermal degradation of biomass, in the absence or at low concentrations of $\mathrm{O}_{2}$ to produce condensable vapors, gases and charcoal Lehmann (2007). Among the various sources used in the production of biochar, the use of chicken litter in Brazil is notable due to the high production generated per year; according to Corrêa and Miele (2011) is around 6.8 million $\mathrm{m}^{3}$. Costa et al. (2009) point out that chicken litter is a viable alternative in agricultural use because it is available on rural properties at low cost. 
Several studies have focused on the beneficial effects of biochar fertilization on the chemical, physical and biological properties of the soil, as well as on increasing biomass accumulation and crop productivity (Kookana et al., 2011; Thomas et al., 2013; Jien \& Wang, 2013). Utomo et al. (2012) verified that the application of $15 \mathrm{t}$ $\mathrm{ha}^{-1}$ of biochar reduced the need for application of nitrogen fertilizer by up to $43 \%$ to produce the same amount of maize dry matter; however, according to Steiner et al. (2007) greater efficiency when it is associated with mineral fertilization due to its low availability of nutrients.

In this sense, the analysis of plant growth is an essential mechanism in ecophysiological studies, because environmental factors such as water and nutrient availability affect the plant growth dynamics. Therefore, with the study of growth rates, it is possible to identify growth efficiency and the ability to adapt to environmental conditions. According to Peixoto et al. (2011), quantitative growth analysis is an accessible and accurate tool to evaluate plant development and the contribution of different physiological processes on its performance in the different soil and climatic conditions that are submitted. On the other hand, the study of production and production components becomes essential to understand the relationship between the factors limiting productivity, which are important variables, affected by nutrition and can help identify the point of maximum productive efficiency. Therefore, this study was set up to evaluate the effect of fertilization with poultry litter biochar in combination with mineral fertilizer under the rates of growth and production of sunflower cv. Embrapa 122/V2000.

\section{Material and Methods}

\subsection{Experimental Site}

The experiment was carried out from September to December 2014 under greenhouse conditions at the Agricultural Engineering Department of the Federal University of Campina Grande, Paraiba State, Brazil $\left(7^{\circ} 13^{\prime} 11^{\prime \prime} \mathrm{S} ; 35^{\circ} 53^{\prime} 31^{\prime \prime} \mathrm{W}\right)$.

\subsection{Design and Treatments}

The experiment was set in a $5 \times 4$ factorial, completely randomized design under five mineral fertilizing (NPK) doses and four poultry litter biochar doses, with four repetitions, total of 80 experimental units. The treatments of mineral fertilizing corresponded to $0,25,50,75$, and 100\% of NPK (100:300:150 mg kg-1) fertilization for testing in greenhouse as Novais et al. (1991) and four poultry litter biochar doses corresponded to $0 \% ; 5 \%$ (400 $\mathrm{g} /$ pot); $10 \%(800 \mathrm{~g} /$ pot $)$ and $15 \%$ (1100 g/pot), calculated based on the soil volume. NPK sources used were, respectively, urea, monoammonium phosphate (MAP) and potassium chloride $(\mathrm{KCl})$, being applied in the treatment with $100 \%$ recommendation $1.41 \mathrm{~g}$ of urea, $13.64 \mathrm{~g}$ of MAP and $5 \mathrm{~g} \mathrm{KCl}$. The MAP was applied every seven days from 25 days after sowing (DAS); $\mathrm{KCl}$ was applied at 30, 45 and 60 DAS and urea was applied to 50 DAS. The biochar was incorporated into the soil and allowed to incubate for a period of 20 days. Carried out also a foliar fertilizer at 40 DAS using Ubyfol ${ }^{\circledR}$ at a ratio of $0.5 \mathrm{~kg}$ of leaf fertilizer for 100 liters of water.

\subsection{Biochar Analysis}

The biochar was produced from conventional pyrolysis process using waste as chicken litter $\left(450{ }^{\circ} \mathrm{C} \times 0.5\right.$ hours $\times$ atmospheric pressure) having as chemical attributes, according to the methodology proposed by the Andrade \& Abreu (2006): $\mathrm{pH}\left(\mathrm{H}_{2} \mathrm{O}\right)=10.2 ; \mathrm{N}=31.8 \mathrm{~g} \mathrm{~kg}^{-1} ; \mathrm{P}=29.4 \mathrm{~g} \mathrm{~kg}^{-1} ; \mathrm{K}=47.16 \mathrm{~g} \mathrm{~kg}^{-1} ; \mathrm{Ca}=48.3 \mathrm{~g} \mathrm{~kg}^{-1} ; \mathrm{Mg}=14.6 \mathrm{~g}$ $\mathrm{kg}^{-1} ; \mathrm{Na}=7.3 \mathrm{~g} \mathrm{~kg}^{-1} ; \mathrm{Fe}=8479 \mathrm{mg} \mathrm{kg}^{-1} ; \mathrm{Cu}=607 \mathrm{mg} \mathrm{kg}^{-1} ; \mathrm{Zn}=1070 \mathrm{mg} \mathrm{kg}^{-1} ; \mathrm{Mn}=650 \mathrm{mg} \mathrm{kg}^{-1}$.

The salinity of the biochar was determined with the following empirical methodology: in a polyethylene tube 12.5 grams of bio-carbon was mixed with $125 \mathrm{~mL}$ of distilled water; then the mixture was passed on a buchner funnel coupled to the kitassate and fitted with cotton (replacing filter paper) in order to avoid the loss of biochar; the drained liquid was chemically analyzed having the following results: $\mathrm{pH}\left(\mathrm{H}_{2} \mathrm{O}\right)=9.39 ; \mathrm{CE}\left(\mathrm{dS} \mathrm{m}^{-1}\right)=8.87 ; \mathrm{P}$ $=56.9 \mathrm{mg} \mathrm{L}^{-1} ; \mathrm{K}=9.6 \mathrm{mg} \mathrm{L}^{-1} ; \mathrm{Ca}=3020.2 \mathrm{mg} \mathrm{L}^{-1} ; \mathrm{Mg}=88.4 \mathrm{mg} \mathrm{L}^{-1} ; \mathrm{Na}=465.1 \mathrm{mg} \mathrm{L}^{-1}$.

\subsection{Soil Analysis}

Each experimental unit consisted of a plastic vase filled with $20 \mathrm{~kg}$ of soil with the following chemical characteristics according to the methodology of EMBRAPA (2011): $\mathrm{pH}\left(\mathrm{H}_{2} \mathrm{O}\right)=6.4 ; \mathrm{Ca}=2.10 \mathrm{cmol}_{\mathrm{c}} \mathrm{kg}^{-1} ; \mathrm{Mg}=$ $2.57 \mathrm{cmol}_{\mathrm{c}} \mathrm{kg}^{-1} ; \mathrm{Na}=0.06 \mathrm{cmol}_{\mathrm{c}} \mathrm{kg}^{-1} ; \mathrm{K}=0.14 \mathrm{cmol}_{\mathrm{c}} \mathrm{kg}^{-1} ; \mathrm{H}+\mathrm{Al}=4.05 \mathrm{cmol}_{\mathrm{c}} \mathrm{kg}^{-1} ; \mathrm{OM}=4.8 \mathrm{~g} \mathrm{~kg}^{-1} ; \mathrm{P}=4.6$ $\mathrm{mg} \mathrm{kg}{ }^{-1} ; \mathrm{pH}_{\mathrm{se}}$ (saturation extract) $=5.8 ; \mathrm{EC}_{\mathrm{se}}=0.22 \mathrm{dS} \mathrm{m}^{-1} ; \mathrm{SAR}$ (sodium adsorption ratio) $=0.75 ; \mathrm{Cl}_{\mathrm{se}}^{-}=1.0$ $\mathrm{mmol}_{\mathrm{c}} \mathrm{L}^{-1} ; \mathrm{CO}_{3}{ }^{2-}{ }_{\mathrm{se}}=0.0 ; \mathrm{HCO}_{3}^{-}{ }_{\mathrm{se}}=1.2 \mathrm{mmol}_{\mathrm{c}} \mathrm{L}^{-1} ; \mathrm{Ca}^{2+}{ }_{\mathrm{se}}=0.25 \mathrm{mmol}_{\mathrm{c}} \mathrm{L}^{-1} ; \mathrm{Mg}^{2+}{ }_{\mathrm{se}}=1.50 \mathrm{mmol}_{\mathrm{c}} \mathrm{L}^{-1} ; \mathrm{Na}^{+}{ }_{\mathrm{se}}=$ $0.70 \mathrm{mmol}_{\mathrm{c}} \mathrm{L}^{-1} ; \mathrm{K}^{+}{ }_{\mathrm{se}}=0.19 \mathrm{mmol}_{\mathrm{c}} \mathrm{L}^{-1}$. 
At the end of the experiment, salinity analysis was carried out in the experimental units to verify the effects of biochar on the chemical attributes of the soil used, using a methodology proposed by EMBRAPA (2011) (Table 1).

Table 1. Mean values of chemical attributes of soil cultivated with sunflower as a function of biochar doses

\begin{tabular}{|c|c|c|c|c|}
\hline Attributes & & & & \\
\hline Saturation extract $\left(\mathrm{mmol}_{\mathrm{c}} \mathrm{L}^{-1}\right)$ & $\mathrm{B}_{1}$ & $\mathrm{~B}_{2}$ & $\mathrm{~B}_{3}$ & $\mathrm{~B}_{4}$ \\
\hline $\mathrm{pH}_{\mathrm{sp}}$ & 5.98 & 7.07 & 7.90 & 8.28 \\
\hline $\mathrm{EC}_{\mathrm{se}}\left(\mathrm{dS} \mathrm{m}^{-1}\right)$ & 3.31 & 7.28 & 9.50 & 9.32 \\
\hline Chloride $\left(\mathrm{Cl}^{-}\right)$ & 33.32 & 47.73 & 50.44 & 50.43 \\
\hline Carbonate $\left(\mathrm{CO}_{3}{ }^{2-}\right)$ & 0.00 & 0.00 & 0.00 & 0.00 \\
\hline Bicarbonate $\left(\mathrm{HCO}_{3}^{-}\right)$ & 2.44 & 2.95 & 5.36 & 7.09 \\
\hline Sulfate $\left(\mathrm{SO}_{4}{ }^{2-}\right)$ & $\mathrm{P}$ & $\mathrm{P}$ & $\mathrm{P}$ & $\mathrm{P}$ \\
\hline Calcium $\left(\mathrm{Ca}^{2+}\right)$ & 7.04 & 7.63 & 3.82 & 3.97 \\
\hline Magnesium $\left(\mathrm{Mg}^{2+}\right)$ & 28.13 & 35.44 & 26.98 & 22.84 \\
\hline Sodium $\left(\mathrm{Na}^{+}\right)$ & 16.98 & 31.03 & 37.01 & 34.71 \\
\hline Potassium $\left(\mathrm{K}^{+}\right)$ & 4.23 & 24.11 & 44.00 & 51.66 \\
\hline SAR & 4.05 & 6.69 & 9.43 & 9.48 \\
\hline
\end{tabular}

Note. $\mathrm{B}_{1}=0 ; \mathrm{B}_{2} 400 \mathrm{~g} /$ pot; $\mathrm{B}_{3}=800 \mathrm{~g} /$ pot; $\mathrm{B}_{4}=1100 \mathrm{~g} /$ pot; $\mathrm{pH}_{\mathrm{sp}}$ : $\mathrm{pH}$ of saturation paste; $\mathrm{EC}_{\mathrm{se}}$ : Saturation extract electric conductivity; SAR: Sodium adsorption ratio.

\subsection{Conduct of the Study}

Three sunflower seeds (cultivar Embrapa 122/V2000) were sown on October 19, 2014 directly in the pots at a 5 $\mathrm{cm}$ depth. Ten and twenty days after sowing (DAS), seedlings were thinned to two and one plant per pot, respectively. The artificial cross-pollination was carried out when the plants reached the R5 stage (beginning of the anthesis), which consisted of using a brush with a good amount of pollen from several flowers produced by different plants, with a quick touch of form to reach all the stigmas. The plants were tutored when they reached the R6 stage (Flowering is complete and the ray flowers are wilting), which includes the end of flowering.

Irrigation was performed daily using rainwater. The applied water volume $(W v)$ was measured using the water consumption by the plants in $100 \% \mathrm{ETr}$, being obtained from the difference between the mean weight of the container in conditions of maximum retention of water $(P c c)$ and the average weight of the containers in the non-saturation condition (current weight) $(P a)$ divided by the number of containers (n).

$$
W v=\frac{P c c-P a}{n}
$$

With plant height and stem diameter data, evaluated at 30,60 and 90 days after sowing the sunflower (DAS) were determined the Absolute Growth Rate and the Relative Growth Rate using the methodology proposed by Benincasa (2004), according to the equations described below:

For the absolute growth rate:

$$
A G R=\frac{\left(A_{2}-A_{1}\right)}{t_{2}-t_{1}} \quad\left(\mathrm{~cm} \mathrm{day}^{-1} \text { or } \mathrm{mm} \mathrm{day}^{-1}\right)
$$

For the relative growth rate:

$$
R G R=\frac{\left(\ln A_{2}-\ln A_{1}\right)}{t_{2}-t_{1}} \quad\left(\mathrm{~cm} \mathrm{~cm}^{-1} \text { day }^{-1} \text { or } \mathrm{mm} \mathrm{mm}^{-1} \text { day }^{-1}\right)
$$

where, $A_{2}=$ height or diameter obtained at the end of the study period; $A_{1}=$ height or diameter obtained at the beginning of the study period; $t_{2}-t_{1}=$ time difference between the samplings.

The production components were evaluated at the time of harvest, being: number of viable achenes (NVA); percentage of non-viable achenes (PNVA) - considering as non-viable achenes, the coarse grains; and production of achenes per plant (PROD).

\subsection{Statistical Analysis}

The experimental data were analyzed by ANOVA using $\mathrm{F}$ test. For significant data regression analysis were used with adjustment of the greatest determination coefficients $(\mathrm{p} \leq 0.05)$. All analyses were performed using 
statistical software SISVAR (Ferreira, 2011). Due to the heterogeneity of the data, the transformation into $\sqrt{X}$ or $\sqrt{X}+1$ was necessary.

\section{Results and Discussion}

The biochar (B) in the experimental units significantly influenced the absolute and relative growth rates of sunflower plant height (AGR-PH and RGR-PH) in the evaluated periods from 30 to 60 DAS and 60 to 90 DAS, in addition, influenced to the absolute growth rate of stem diameter (AGR-SD) in the evaluated period from 30 to 60 DAS (Table 2). It is also observed the significant effect of fertilization with NPK (D) on the AGR-SD in the period from 30 to 60 DAS; however, there was no significant effect for interaction between the factors (D x B) for any variable analyzed. These results show that biomass increase as a function of time (growth rate) remained constant at all levels of fertilization. Ribeiro et al. (2016) did not observe a significant effect of nitrogen fertilization under sunflower growth rates. Corroborating, Furtado et al. (2014) did not find a significant effect of potassium fertilization under AGR-PH and RGR-PH in the evaluation period of 35-60 DAS.

Table 2. Summary of 'F' test for absolute and relative growth rate of plant height (AGR-PH and RGR-PH) and stem diameter (AGR-SD and RGR-SD) of sunflower in the evaluation periods performed between 30-60 and 60-90 days after sowing (DAS) as a function of doses of NPK and biochar

\begin{tabular}{|c|c|c|c|c|c|}
\hline \multirow{2}{*}{ Growth Rate } & \multirow{2}{*}{ Source of Variation } & \multicolumn{4}{|c|}{ 'F' Test } \\
\hline & & AGR-PH & AGR-SD & RGR-PH & RGR-SD \\
\hline \multirow[t]{8}{*}{ 30-60 DAS } & Doses (D) & ns & $* *$ & ns & ns \\
\hline & Linear Regression & - & Ns & - & - \\
\hline & Quadratic Regression & - & $* *$ & - & - \\
\hline & Biochar (B) & $* *$ & $*$ & $*$ & - \\
\hline & Linear Regression & $* *$ & $*$ & $*$ & - \\
\hline & Quadratic Regression & $\mathrm{ns}$ & Ns & $*$ & ns \\
\hline & $\mathrm{D} \times \mathrm{B}$ & $\mathrm{ns}$ & Ns & $\mathrm{ns}$ & $\mathrm{ns}$ \\
\hline & $\mathrm{VC}(\%)$ & 22.25 & 30.61 & 14.67 & 33.06 \\
\hline \multirow[t]{7}{*}{ 60-90 DAS } & & AGR-PH $^{1}$ & AGR-SD $^{1}$ & RGR-PH $^{1}$ & RGR-SD $^{1}$ \\
\hline & Doses (D) & ns & Ns & ns & ns \\
\hline & Biochar (B) & $* *$ & - & $* *$ & - \\
\hline & Linear Regression & $* *$ & - & $* *$ & - \\
\hline & Quadratic Regression & $*$ & Ns & $*$ & ns \\
\hline & $\mathrm{D} \times \mathrm{B}$ & ns & Ns & ns & ns \\
\hline & $\mathrm{VC}(\%)$ & 42.47 & 37.85 & 45.84 & 35.56 \\
\hline
\end{tabular}

Note. $(* *),(*),(\mathrm{ns}):(\mathrm{p} \leq 0.01)$ and $(\mathrm{p} \leq 0.05)$ and not significant respectively; ${ }^{1}$ Statistical analysis performed after data transformation in $\sqrt{X}$.

According to regression studies for AGR-SD as a function of NPK doses (Figure 1), the data were adjusted for the quadratic model; the highest value being obtained at a dose of $60 \%$ of the recommendation $\left(0.1902 \mathrm{~mm} \mathrm{day}^{-1}\right)$ and from that point there was a reduction of $8.41 \%$. It is also seen that the increase provided with increasing NPK levels between 0 and $60 \%$ of the recommendation was $18.93 \%$. According to Furtado et al. (2014), potassium fertilization promotes an increase in sunflower AGR-SD up to the dose of $100 \mathrm{mg} \mathrm{kg}^{-1}$ of soil in the evaluation period from 35 to 60 DAS. Maia Junior et al. (2013) verified, for the same cultivar, a mean AGR-SD of $0.0974 \mathrm{~mm} \mathrm{day}^{-1}$ in the evaluation period of 20 to 80 DAS. 


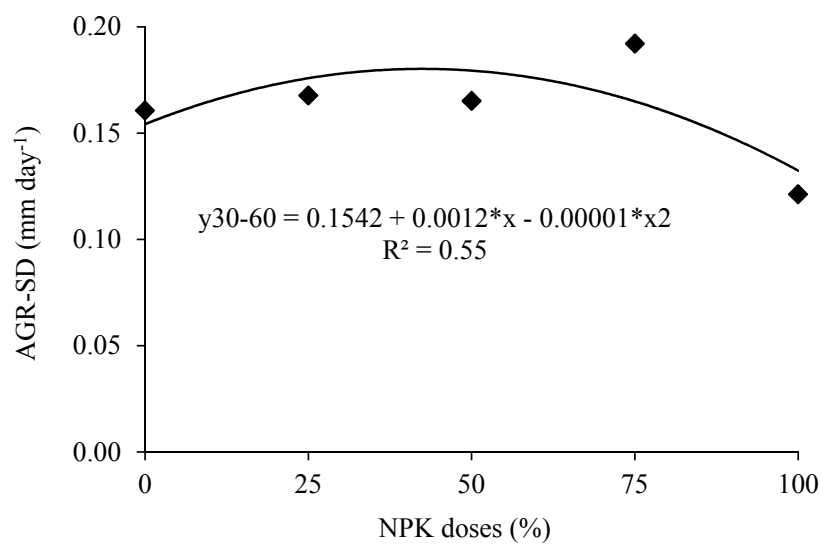

Figure 1. Absolute growth rate of stem diameter (AGR-SD) in the evaluation period performed between 30-60 days after sowing of sunflower (DAS) as a function of NPK doses (\%)

The increase of the bichar doses promoted linear reduction of the AGR-PH of sunflower in the period from 30 to 60 DAS (Figure 2A). The lowest value of AGR-PH was $1.48 \mathrm{~cm} \mathrm{day}^{-1}$ when the plants received fertilization with $1100 \mathrm{~g} /$ pot of biochar, corresponding to a decrease of $34.25 \%$ in relation to plants that were not fertilized with biochar $\left(2.25 \mathrm{~cm} \mathrm{day}^{-1}\right)$. These results are related to the effect of saline stress due to the application of biochar in the soil as verified in Table 1. Ribeiro et al. (2016) found a reduction on the sunflower growth rate in the period 31-45 DAS under conditions of salt stress. Maia Junior et al. (2013) working with cv. Embrapa 122/V2000, observed, on average, AGR-PH of $1.31 \mathrm{~cm} \mathrm{day}^{-1}$ in the evaluation period of 20-80 DAS. The inhibition of the growth of plants under conditions of salt stress is due to the reduction of the osmotic potential of the soil solution to levels that make it impossible to absorb water and nutrients, together with the ionic toxicity due to the excess accumulation of certain ions in the tissues vegetables (Flowers, 2004).

The vegetative growth rates are variables used to determine plant growth at different stages of development and are dependent on the amount material of previously accumulated. These variables represent increase in height or mass, as a function of time (absolute growth) or growth per unit of time, expressed in a mass, area and length initial (relative growth) (Taiz \& Zeiger, 2013). Because of this, through these variables, it is possible to determine the intensity of biotic or abiotic stress on plant growth.

Based on the regression studies for AGR-PH in the period from 60 to 90 DAS (Figure 2B), the model that best fit was the quadratic one indicating that the increase of the biochar dose up to $785.7 \mathrm{~g} /$ pot promoted an increase in the AGR-PH of $67.00 \%$ in relation to the plants that were not fertilized and from this point there was a decrease of $10.71 \%$ in relation to the highest dose; these results can be justified by the greater adaptation of the culture after 60 DAS. Corroborating, Ribeiro et al. (2016) found no significant effect of salt stress on sunflower growth rates in the 46-60 and 61-75 DAS assessment periods; these authors also point out that these results are related to permanent osmotic adjustment, which is a mechanism that allows halophyte plants to live in saline stress conditions. 

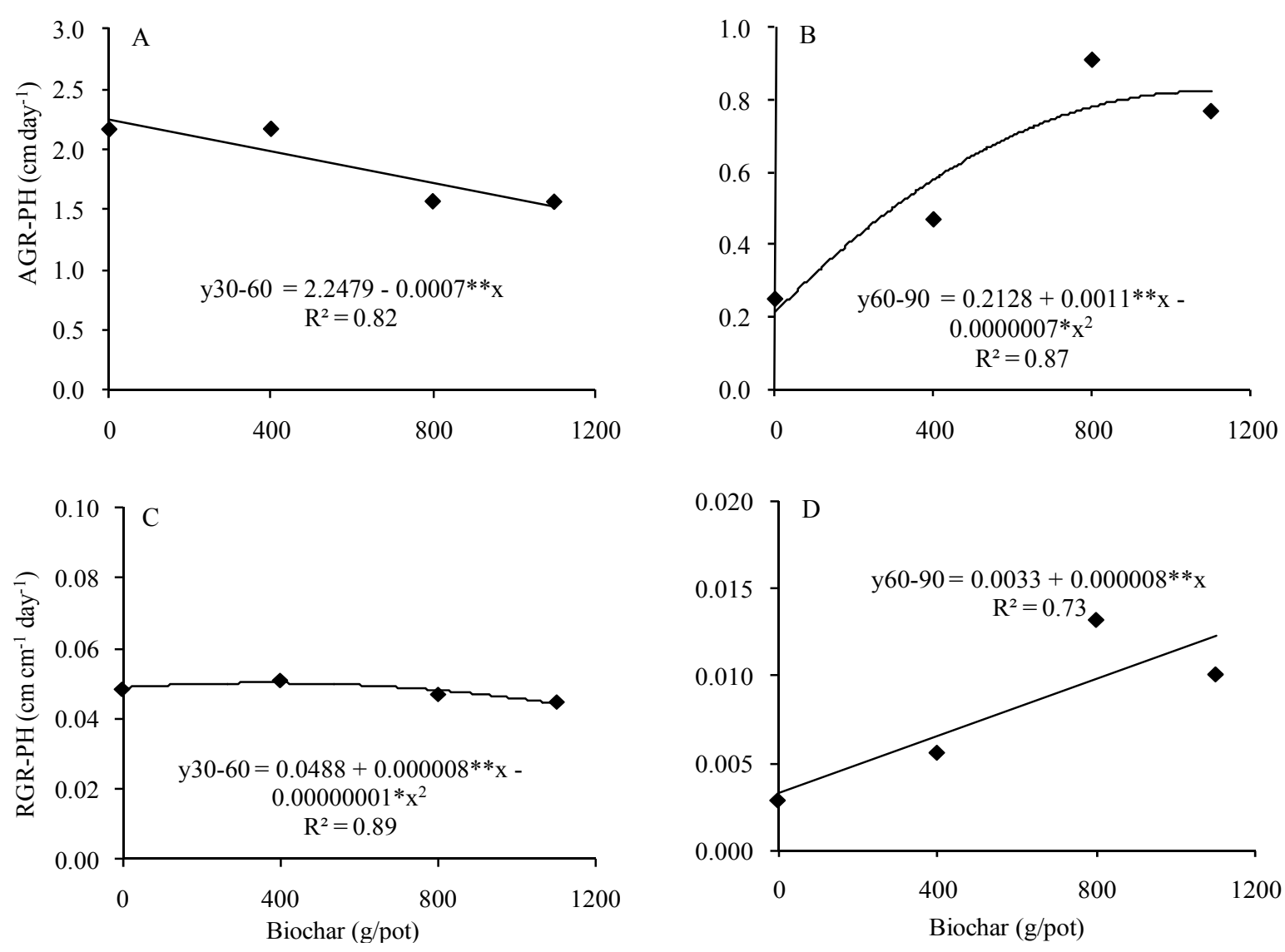

Figure 2. Absolute growth rate of plant height (AGR-PH) in the evaluation period between 30-60 (A) and 60-90 (B) days after sunflower seeding and relative growth rate of plant height (RGR-PH) at 30-60 (C) and 60-90 (D) days after sunflower seeding as a function of doses of biochar

According to regression equations, a quadratic effect is observed for RGR-PH of sunflower in the period from 30 to 60 DAS (Figure 2C), in which the dose of biochar from $400 \mathrm{~g} /$ pot led to a decrease of $9.72 \%$ in the RGR-PH; however, the RGR-PH in the period from 60 to 90 DAS increased linearly with the increment of the doses of biochar being the highest values obtained with the dose of $1100 \mathrm{~g} /$ pot $\left(0.0121 \mathrm{~cm} \mathrm{~cm}^{-1}\right.$ day $\left.^{-1}\right)$, which promoted an increase of $72.73 \%$ in relation to the plants that did not receive fertilization with biochar (Figure 2D). Based on these results, it was observed that the RGR-PH followed the same trend observed for the AGR-PH (Figures 2A and $2 \mathrm{~B}$ ), noting that after 60 DAS there was possibly a greater adaptation of the culture to the stress conditions.

The application of increasing doses of NPK in the experimental units had a significant effect on the components of sunflower production (Table 3) corroborating Jahangir et al. (2006), which verified a significant effect of fertilization with $\mathrm{N}$ and $\mathrm{P}$ on the yield of sunflower grains. Biochar significantly affected the number of viable achenes (NVA) and production of achenes per plant (PROD). According to Suppadit et al. (2012) biochar had a significant effect on soy production components. There is also a significant effect of the interaction between the factors $\mathrm{D} \times \mathrm{B}$ for PROD (Table 3 ). 
Table 3. Summary of the ' $F$ ' test for number of viable achenes (NVA), percentage of non-viable achenes (PNVA) and production of achenes per plant (PROD) as a function of NPK doses and biochar

\begin{tabular}{llll}
\hline \multirow{2}{*}{ Source of Variation } & \multicolumn{3}{c}{ 'F' Test } \\
\cline { 2 - 4 } & NVA & PNVA $^{1}$ & PROD \\
\hline Doses (D) & $* *$ & $* *$ & $* *$ \\
Linear Regression & $\mathrm{ns}$ & Ns \\
Quadratic Regression & $* *$ & $\mathrm{Ns}$ & $* *$ \\
Biochar (B) & $* *$ & - & $* *$ \\
Linear Regression & $* *$ & - & $* *$ \\
Quadratic Regression & $*$ & $\mathrm{Ns}$ & $* *$ \\
$\mathrm{D} \times \mathrm{B}$ & $\mathrm{ns}$ & 36.75 & $*$ \\
$\mathrm{VC}(\%)$ & 16.74 & 28.79 \\
\hline
\end{tabular}

Note. $\left({ }^{* *}\right),\left({ }^{*}\right),(\mathrm{ns}):(\mathrm{p} \leq 0.01)$ and $(\mathrm{p} \leq 0.05)$ and not significant respectively; ${ }^{1}$ Statistical analysis performed after data transformation in $\sqrt{X}+1$.

According to the regression equation (Figure 3A), NPK doses had a quadratic effect on the number of viable achenes of the sunflower (NVA), indicating that the dose increase up to $54.48 \%$ (374 units) of the NPK recommendation promoted an increase of $41.95 \%$ in relation to the lowest dose. It is also observed that from this point, there was a reduction of $29.25 \%$ in relation to the plants that received $100 \%(\mathrm{~N}: \mathrm{P}: \mathrm{K}, 100: 300: 150 \mathrm{~g} / \mathrm{pot})$ of the recommendation. The fertilization around $50 \%$ of the NPK recommendation promoted higher NVA, which is justified by the adequate availability of nutrients, especially in the flowering stage (Stage R1).
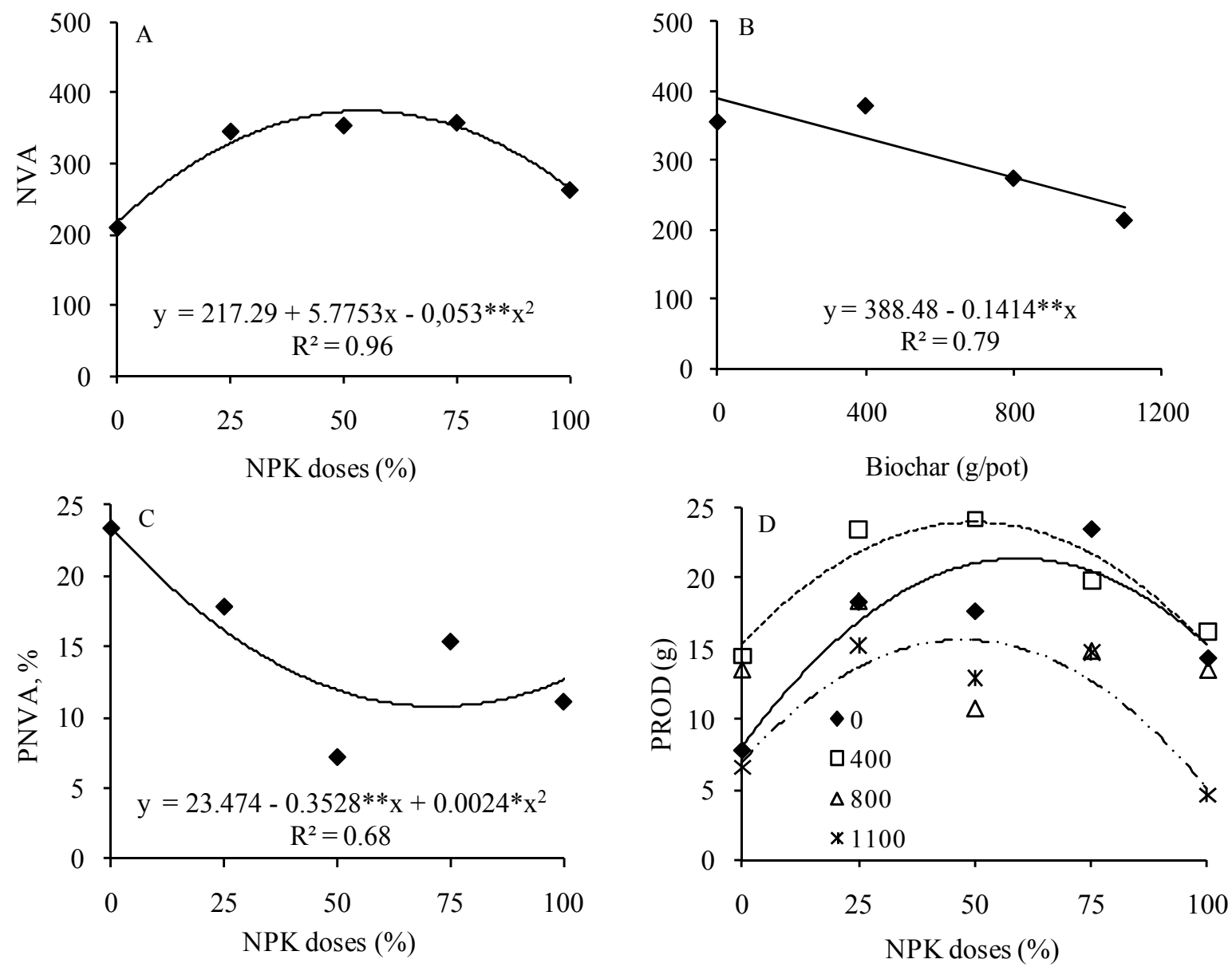

Figure 3. Number of viable achenes - NVA as a function of doses of NPK - $\%$ (A) and biochar - $g /$ pot (B); percentage of non-viable achenes - PNVA as a function of NPK doses - $\%(C)$; split of the interaction between the factors for production of achenes per plant - PROD (D) 
Biochar fertilization reduced linearly the NVA of the sunflower (Figure 3B); the lowest value was observed with the dose of $1100 \mathrm{~g} / \operatorname{pot}(233 \mathrm{units}$ ), which corresponded to a reduction of $40.03 \%$ with reference to the plants that were not fertilized with biochar (388 units). Again, the effect of increasing soil salinity from fertilization with biochar is observed. The increase of the excess soluble salts in the soil promotes an increase in the osmotic potential and a reduction of the water potential, reducing the photosynthetic rate and, consequently, the production of photoassimilates to the reproductive organs. Santos Junior et al. (2011a) verified a linear reduction of the NVA with the increase of the electric conductivity (EC) of the irrigation water and obtained, on average, 300 units at the level of $4.3 \mathrm{dS} \mathrm{m}^{-1}$. Corroborating Centeno et al. (2014) verified a linear reduction of the percentage of viable achenes with the increment of the $\mathrm{EC}$ of the irrigation water.

The results of the PNVA as a function of the NPK doses were better adjusted to the decreasing quadratic model, indicating that the increase of the fertilization up to the $73.5 \%$ dose of the recommendation promoted reduction of the PNVA of $55.23 \%$ in relation to the lowest dose and from this point there is an increase of $13.78 \%$ in relation to the dose of $100 \%$ of the recommendation (Figure 3C). These results are justified by the greater nutritional availability close to the $50 \%$ dose of the recommendation. The PNVA ranged from $10.51 \%$ to $23.47 \%$, however, these values are lower than those reported by Santos Júnior et al. (2011b) which obtained a change from $21.70 \%$ to $35.81 \%$. According to Garcia et al. (2010), progressive saline stress may induce ionic toxicity and/or nutritional imbalance due to the excessive accumulation of ions in the cellular protoplasm, and may cause cellular injury through oxidative stress, which may result in a decrease in the number of achenes, mass of achenes and, consequently, greater number of pimples. It is also verified that the PNVA presented an opposite tendency to the behavior of the NVA (Figure 3A), which shows consistency between the results, that is, as there is an increase in NVA there is reduction of the PNVA, a fact that is justified seen that the estimated maximum doses were close.

The production of achenes per plant (PROD) as a function of increasing doses of NPK, submitted to fertilization with 0,400 , and $1100 \mathrm{~g} /$ pot of biochar, increased up to the dose of $59.17 \%$ (21.29 g/plant), $49.60 \%$ (23.91 $\mathrm{g} /$ plant) and $48.06 \%$ (15.68 g/plant) of the recommendation respectively, that is, the highest yields were close to the 50\% dose of the NPK recommendation. The lowest values were estimated for the 100\% (100:300:150 mg $\mathrm{kg}^{-1}$ ) of the NPK recommendation and the dosage of $800 \mathrm{~g} / \mathrm{pot}$ of biochar there is no significant effect on the PROD, reaching an average value of $14.21 \mathrm{~g} /$ plant (Figure 3D and Table 4). According to Yasin et al. (2013) the mass of achenes expresses the degree of development of the grain and plays a fundamental role in the evaluation of the potential yield of a crop. According to Banerjee et al. (2014) the combination of 100: $50: 50 \mathrm{~kg} \mathrm{ha}^{-1}$ of NPK promoted higher yield of sunflower achenes $\left(1465.15 \mathrm{~kg} \mathrm{ha}^{-1}\right)$. For Jahangir et al. (2006) the combination of $120 \mathrm{~kg} \mathrm{ha}^{-1}$ of $\mathrm{N}$ and $75 \mathrm{~kg} \mathrm{ha}^{-1}$ of $\mathrm{P}_{2} \mathrm{O}_{5}$ promoted higher yields of achenes $\left(2,001 \mathrm{~kg} \mathrm{ha}^{-1}\right)$; however, Ali \& Noorka (2013) observed better yield of sunflower with the combination of 135 and $75 \mathrm{~kg} \mathrm{ha}^{-1}$ of N and P (2,584 $\left.\mathrm{kg} \mathrm{ha}^{-1}\right)$.

Table 4. Regression equations for the production of achenes by sunflower plant as a function of doses of NPK and Biochar

\begin{tabular}{llll}
\hline \multicolumn{4}{c}{ Production per Plant $(\mathrm{g})$} \\
\hline Biochar $(\mathrm{g} / \mathrm{pot})$ & Equation & $\mathrm{R}^{2}$ & Mean \\
\hline 0 & $\mathrm{Y}=7.9742+0.4497 * \mathrm{x}-0.0038^{* *} \mathrm{x}^{2}$ & 0.82 & 16.34 \\
400 & $\mathrm{Y}=15.308+0.3472 \mathrm{x}-0.0035^{* *} \mathrm{x}^{2}$ & 0.89 & 19.62 \\
1100 & $\mathrm{Y}=6.9056+0.3653 \mathrm{x}-0.0038^{* *} \mathrm{x}^{2}$ & 0.86 & 10.80 \\
\hline
\end{tabular}

Note. $\left({ }^{* *}\right),\left({ }^{*}\right)$ significant at $(\mathrm{p} \leq 0.01)$ and $(\mathrm{p} \leq 0.05) ; \mathrm{Y}=$ production of achenes per plant $(\mathrm{g} / \mathrm{plant}) ; \mathrm{x}=$ doses of NPK (\%).

It is observed that, although the fertilization with biochar reduced NVA values (Figure 3B), the dose of $400 \mathrm{~g} / \mathrm{pot}$ (19.62 g/plant) promoted an increase in the PROD of $16.72 \%$ in relation to the plants which were not fertilized with biochar (16.34 g/plant). According to Suppadit et al. (2012) the application of $98.6 \mathrm{~g} / \mathrm{pot}$ of biochar promoted a higher yield of soybean seeds. According to Tagoe et al. (2008) the combination of $11.4 \mathrm{~g} / \mathrm{pot}$ of biochar with $410 \mathrm{mg} \mathrm{kg}^{-1}$ of $\mathrm{K}$ increased the yield of soybeans and cowpea, respectively, of 53 and $185 \%$ in relation to the control (without fertilization). It was also observed that the dose of $1100 \mathrm{~g} / \mathrm{pot}(10.80 \mathrm{~g} / \mathrm{plant})$ promoted a reduction of $44.95 \%$ in the PROD in relation to the dose of $400 \mathrm{~g} /$ pot, probably due to excess salts in the soil. 
Saline stress promotes metabolic disturbances in plants, affecting their physiology, promoting a reduction in the absorption of water and soil nutrients, mainly due to the reduction of the leaf area, implying a lower photosynthetic surface and, consequently, lower crop yield (Lima et al., 2014). Nobre et al. (2011) observed a linear reduction of the PROD with the increment of the EC of the irrigation water, obtaining $17.4 \mathrm{~g} / \mathrm{plant}$ when the plants were irrigated with higher levels of EC. Centeno et al. (2014) also observed similar results.

\section{Conclusions}

Biochar fertilization promoted an increase in sunflower growth rates in the evaluation periods.

The fertilization with $400 \mathrm{~g} /$ pot of biochar promoted a $16.72 \%$ increase in the production of achenes per plant.

The combination of 50: 150: $75 \mathrm{mg} \mathrm{kg}^{-1}$ of NPK and $400 \mathrm{~g} /$ pot of biochar promoted higher sunflower yield (23.91 g/plant).

\section{References}

Ali, A., \& Noorka, I. R. (2013). Nitrogen and phosphorus management strategy for better growth and yield of sunflower (Helianthus annuus L.) hybrid. Soil \& Environment, 32, 44-48.

Andrade, J. C., \& Abreu, M. F. (2006). Análise Química de Residuos Sólidos para Monitoramento e Estudos Agroambientais (p. 178). Instituto Agronômico, Campinas.

Banerjee, H., Dutta, S. K., Pramanik, S. J., Ray, K., Phonglosa, A., \& Bhattacharyya, K. (2014). Productivity and profitability of spring planted sunflower hybrid with nitrogen, phosphorus and potassium fertilizer. Annals of Plant and Soil Research, 16, 250-256.

Benincasa, M. M. P. (2004). Análise de crescimento de plantas (noções básicas). FUNEP, Jaboticabal, 42p.

Campos, V. B., Chaves, L. H. G., Guerra, H. O. C., Guedes Filho, D. H., \& Santos Junior, J. A. (2012). Adubação NPK e conteúdo de água disponível no solo na cultura do girassol para fins ornamentais. Congresso Norte e Nordeste de Pesquisa e Inovação, 7. Anais... Palmas. Retrieve January 15, 2017, from http://propi.ifto.edu.br/ocs/index.php/connepi/vii/paper/viewFile/28/1328

Castro, C., \& Oliveira, F. A. (2005). Nutrição e Adubação do Girassol. In R. M. V. B. C. Leite, A. M. Brighenti, \& C. Castro (Eds.). Girassol no Brasil (pp. 317-373). Embrapa Soja, Londrina.

Centeno, C. R. M., Santos, J. B., Xavier, D. A., Azevedo, C. A. V., \& Gheyi, H. R. (2014). Components of production of sunflower Embrapa 122-V2000 under water salinity and nitrogen fertilization. Revista Brasileira de Engenharia Agrícola e Ambiental, 18(Supl.), 539-545. http://doi.org/10.1590/1807-1929/ agriambi.v18nsupps39-s45

Corrêa, J. C., \& Miele, M. (2011). A cama de aves e os aspectos agronômicos, ambientais e econômicos. In J. C. P. Palhares \& A. Kunz (Eds.), Manejo ambiental na aviculture (pp. 125-152). Embrapa Suínos e Aves, Concórdia.

Costa, A. M., Borges, E. N., Silva, A. A., Nolla, A., \& Guimarães, E. C. (2009). Potencial of physical recovery of a red latosol, under degraded pasture, as affected by the apllication of chicken. Ciência Agrotecnológica, 33, 1991-1998. http://doi.org/10.1590/S1413-70542009000700050

EMBRAPA (Empresa Brasileira de Pesquisa Agropecuária). (2011). Manual e métodos de análise de solo (p. 230). Embrapa Solos, Rio de Janeiro.

Ferreira, D. F. (2011). Sisvar: A computer statistical analysis system. Ciencia e Agrotecnologia, 35, 1039-1042. http://doi.org/10.1590/S1413-70542011000600001

Flowers, T. J. (2004). Improving crop salt tolerance. Journal of Experimental Botany, 55, 307-319. https://doi.org/10.1093/jxb/erh003

Furtado, G. F., Xavier, D. A., Andrade, E. M. G., Soares, L. A. A., Sousa, J. R. M., \& Lima, G. S. (2014). Taxas de crescimento do girassol cultivado sob diferentes níveis de reposição hídrica e doses de $K$ (pp. 257-260). UMS: Congresso de Uso e Manejo do Solo, 6. Anais... Recife.

Garcia, G. O., Nazário, A. A., Moraes, W. B., Gonçalves, I. Z., \& Madalão, J. C. (2010). Selection of bean varieties for salinity tolerance. Engenharia na Agricultura, 18, 330-338. https://doi.org/10.13083/ 1414-3984.v18n04a07

Jahangir, A. A., Mondal, R. K., Nada, K., Afroze, S. R., \& Hakim, M. A. (2006). Response of nitrogen and phosphorus fertilizer and plant spacing on growth and yield contributing character of sunflower. Bangladesh Journal of Science and Industrial Research, 41, 33-40. http://doi.org/10.3329/bjsir.v41i1.258 
Jien, S.-H., \& Wang, C. S. (2013). Effects of biochar on soil properties and erosion potential in a highly weathered soil. Catena, 110, 225-233. http://doi.org/10.1016/j.catena.2013.06.021

Kookana, R. S., Sarmah, A. K., Zwieten, L. van, Krull, E., \& Singh, B. (2011). Biochar application to soil: Agronomic and environmental benefits and unintended consequences. Advances in Agronomy, 112, 103-143. http://doi.org/10.1016/B978-0-12-385538-1.00003-2

Lehmann, J. (2007). Bio-energy in the black. Frontiers in Ecology and the Environment, 5, $381-387$. http://doi.org/10.1890/1540-9295(2007)5[381:BITB]2.0.CO;2

Lehmann, J., Gaunt, J., \& Rondon, M. (2006). Bio-char sequestration in terrestrial ecosystems-A review. Mitigation and Adaptation Strategies for Global Change, 11, 403-427. http://doi.org/10.1007/s11027005-9006-5

Lima, G. S., Nobre, R. G., Gheyi, H. R., Soares, L. A. A., \& Silva, A. O. (2014). Growth and components of production of castor bean under saline stress and nitrogen fertilization. Engenharia Agrícola, 34, 854-866. http://doi.org/10.1590/S0100-69162014000500005

Madari, B. E., Maia, C. M. B. F., \& Novotny, E. H. (2012). Context and importance of biochar research. Pesquisa Agropecuária Brasileira, 47, i-ii. http://doi.org/10.1590/S0100-204X2012000500001

Maia Junior, S. O., Andrade, J. R., Araújo, D. L., Sousa, J. S., \& Medeiros, I. F. S. (2013). Growth rates of sunflower under different variety of water schemes. Revista Verde de Agroecologia e Desenvolvimento Sustentável, 8, 150-155. http://doi.org/10.18378/rvads.v8i3.2310

Nobre, R. G., Gheyi, H. R., Soares, F. A. L., \& Cardoso, J. A. F. (2011). Sunflower production under saline stress and nitrogen fertilization. Revista Brasileira de Ciência do Solo, 35, 929-937. http://doi.org/10.1590/ S0100-06832011000300027

Novais, R. F., Neves, J. C. L., \& Barros, N. F. (1991). Ensaio em ambiente controlado. In A. J. Oliveira (Ed.), Métodos de pesquisa em fertilidade do solo (pp. 189-253). EMBRAPA-SEA, Brasília.

Peixoto, C. C., Cruz, T. V., \& Peixoto, M. F. S. P. (2011). Análise quantitativa do crescimento de plantas: Conceitos e prática. Enciclopédia Biosfera, 7, 51-76.

Prado, R. M., \& Leal, R. M. (2006). Nutritional disorders by deficiency in sunflower var. Catissol-01. Pesquisa Agropecuária Tropical, 36, 187-193.

Ribeiro, P. H. P., Gheyi, H. R., Uyeda, C. A., Teixeira, M. B., Soares, F. A. L., \& Dias, N. S. (2016). Growth rates and production of sunflower irrigated with saline water and nitrogen doses. Irriga, 1(1), $233-247$. http://doi.org/10.15809/irriga.2016v1n1p233-247

Santos Júnior, J. A., Gheyi, H. R., Dias, N. S., Soares, F. A. L., \& Nobre, R. G. (2011b). Levels of boron and wastewater in production of sunflower. Revista Ciência Agronômica, 42, 857-864. http://doi.org/10.1590/ S1806-66902011000400006

Santos Júnior, J. A., Gheyi, H. R., Guedes Filho, D. H., Dias, N. S., \& Soares, F. A. L. (2011a). Sunflower cultivation in a hydroponic system under different salinity levels. Revista Ciência Agronômica, 42, 842-849. http://doi.org/10.1590/S1806-66902011000400004

Steiner, C., Teixeira, W. G., Lehmann, J., Nehls, T., Macêdo, J. L. V., Blum, W. E. H., \& Zech, W. (2007). Long term effects of manure, charcoal and mineral fertilization on crop production and fertility on a highly weathered Central Amazonian upland soil. Plant Soil, 291, 275-290. https://doi.org/10.1007/s11104-0079193-9

Suppadit, T., Phumkokrak, N., \& Poungsuk, P. (2012). The effect of using quail litter biochar on soybean (Glycine max [L.] Merr.) production. Chilean Journal of Agricultural Research, 72, $244-251$. https://doi.org/10.4067/S0718-58392012000200013

Tagoe, S. O., Horiuchi, T., \& Matsui, T. (2008). Preliminary evaluation of the effects of carbonized chicken manure, refuse derived fuel and $\mathrm{K}$ fertilizer application on the growth, nodulation, yield, $\mathrm{N}$ and $\mathrm{P}$ contents of soybean and cowpea in the greenhouse. African Journal of Agricultural Research, 3, 759-774.

Taiz, L., \& Zeiger, E. (2013). Fisiologia vegetal (5th ed., p. 918). Artmed, Porto Alegre.

Thomas, S. C., Frye, S., Gale, N., Garmon, M., Launchbury, R., Machado, N., ... Winsborought, C. (2013). Biochar mitigates negative effects of salt additions on two herbaceous plant species. Journal of Environmental Management, 129, 62-68. https://doi.org/10.1016/j.jenvman.2013.05.057 
Utomo, W. H., Guritno, B., \& Soehono, L. A. (2012). The effect of biochar on the growth and N fertilizer requirement of maize (Zea mays L.) in green house experiment. Journal of Agricultural Science, 4, 255-262. https://doi.org/10.5539/jas.v4n5p255

Yasin, M., Mahmood, A., Ali, A., Aziz1, M., Javaid, M. M., Iqbal, Z., \& Tanveer, A. (2013). Impact of varying planting patterns and fertilizer application strategies on autumn-planted sunflower hybrid. Cercetari Agronomice in Moldova, 46, 39-51. https://doi.org/10.2478/v10298-012-0082-x

Zobiole, L. H. S., Castro, C., Oliveira, F. A., \& Oliveira Junior, A. (2010). Macronutrient uptake of sunflower (Helianthus annuus L.). Revista Brasileira de Ciências do Solo, 34, 425-433. https://doi.org/10.1590/ S0100-06832010000200016

\section{Copyrights}

Copyright for this article is retained by the author(s), with first publication rights granted to the journal.

This is an open-access article distributed under the terms and conditions of the Creative Commons Attribution license (http://creativecommons.org/licenses/by/4.0/). 